Ann. Génét. Sél. anim., 1982, 14 (1), 43-48

\title{
Relationship between serum alkaline phosphatase genetic polymorphism and activity of the enzyme in Large White pigs
}

\author{
T. PRZYTULSKI, M. KOĆWIN-PODSIADLY and A. KLEMKE \\ Institute of Animal Breeding and Technology of Animal Production, \\ Academy of Agriculture, 71-460 Szczecin, Judyma 6 Poland
}

\section{Summary}

In a fopulation of 1165 Large White pigs, three different serum alkaline phosphatase $(A k p)$ types (AB 6.78 p. 100 , BB 83.60 p. 100 and $\mathrm{BC} 9.62$ p. 100) were found. The $A k p$ activity of the $\mathrm{AB}$ type was significantly $(\mathrm{P}<0.01)$ higher in comparison to the $\mathrm{BB}$ and $\mathrm{BC}$ types and the $\mathrm{BB}$ type had lower activity than the $\mathrm{BC}$ type $(\mathrm{P}<0.05)$. The $Z n$ level of the $\mathrm{AB}$ type was higher than those of $\mathrm{BB}$ and $\mathrm{BC}$ types $(\mathrm{P}<0.05)$. The correlation between activity of $A k p$ and $Z n$ level in serum was highly significant $(+0.535)$. The $C a$ level of the $\mathrm{BC}$ type was higher than those of the $\mathrm{BB}(\mathrm{P}<0.05)$ and $\mathrm{AB}(\mathrm{P}<0.01)$ types. On the basis of these results it is concluded that serum $A k p$ activity and $Z n$ and $C a$ levels are genetically controlled through the $A k p$ genotype.

\section{I. - Introduction}

Alkaline phosphatase (EC 3.1.3.1.) is the enzyme which catalyses the hydrolysis of orthophosphoric monoesters. The basic reaction of alkaline phosphatase $(A k p)$ is as follows :

$$
\mathrm{R}-\mathrm{O}-\mathrm{PO}_{3} \mathrm{H}_{2}+\mathrm{H}_{2} \mathrm{O} \rightarrow \mathrm{R}-\mathrm{OH}+\mathrm{H}_{3} \mathrm{PO}_{4}
$$

The activating ions are $\mathrm{Zn}^{2+}, \mathrm{Mg}^{2+}$ and $\mathrm{Ca}^{2+}$ (Comar \& Bronne, 1961 ; StankieWICZ, 1978).

Dinklage (1968) described polymorphism of serum $A \mathrm{kp}$ in pigs of German Improved Landrace and Göttingen Miniature breeds. $A k p$ is controlled by five alleles $A k p^{\mathrm{A}}, A k p^{\mathrm{B}}, A k p^{\mathrm{C}}, A k p^{\mathrm{D}}$ and $A k p^{\mathrm{E}}$. $A k p$ heterogeneity has been also analyzed by SAISON (1968), ZAGULSKA (1976) and KIEREK-JASZCZUK et al. (1978).

RASMUSEN (1963) reported no variation in the sera of pigs of the Duroc, Landrace and Yorkshire breeds. Other workers have also failed to find polymorphism in pig sera (BAKER, 1967 ; WIDDOWSON, 1967).

The aim of our investigations was to determine the serum $A k p$ polymorphism in Large White pigs as well as its relationship with $A k p$ activity and mineral levels. 


\section{Material and methods}

Serum samples from 1165 animals were tested. Fractions of blood serum $A k p$ were determined by the method of starch gel electrophoresis according to SMITHIES (1955) in the buffer system of GAHNE (1963).

The relationship between types and activity of $A k p$ was carried out on 288 pigs. The Large White pigs were taken from one farm and included 288 daughters and sons of 11 boars and 42 sows. Blood samples were taken from the anterior vena cava one time at the age of 5 months.

Activity of $A k p$ was measured by the Alkaline Phosphatase-Test (Fermognost, East Germany). This method is based on the method described by BEsSEY et al. (1946). Levels of mineral $(\mathrm{Zn}, \mathrm{Ca}, \mathrm{Mg})$ in the serum were assayed by the atomic absorption spectrophotometry (SP 1900, Pye Unicam).

The results were statistically analyzed by the analysis of variance ( $F$ - test) and correlation coefficients.

\section{II. - Results}

In the population of 1165 head of pigs studied three different $A k p$ types AB, $\mathrm{BB}$ and $\mathrm{BC}$ were observed as shown in table 1. The frequency of $\mathrm{BB}$ type was very high (83.60 p. 100) and the $A k p \mathrm{AB}$ and $\mathrm{BC}$ types occured at a lower frequencies of 6.78 and 9.62 p. 100 , respectively. In the present study the inheritance type of $A k p$ was not analyzed. Comparison of the observed and the expected distribution of $A k p$ phenotypes in the population studied shows that the population deviates significantly from equilibrium $(\mathrm{P}<0.05$, table 1$)$.

\section{TABLE 1}

Frequencies of serum Akp genotypes and alleles.

Fréquences des génotypes et des allèles Akp.

\begin{tabular}{|c|c|c|c|c|c|}
\hline & \multirow{2}{*}{ Genotypes } & \multicolumn{2}{|c|}{ Observed } & \multirow{2}{*}{ Expected } & \multirow{2}{*}{$\mathrm{Chi}^{2}$ (3 d.f.) } \\
\hline & & No. & $\%$ & & \\
\hline$N=1165$ & $\begin{array}{l}\mathrm{AB} \ldots \ldots \\
\mathrm{BB} \\
\mathrm{BC} \\
\mathrm{BC} \\
\mathrm{AA} \\
\mathrm{CC} \\
\mathrm{CC}\end{array}$ & $\begin{array}{r}79 \\
974 \\
112 \\
0 \\
0 \\
0\end{array}$ & $\begin{array}{r}6.8 \\
83.6 \\
9.6 \\
0 \\
0 \\
0\end{array}$ & $\begin{array}{r}72.7 \\
981.8 \\
102.7 \\
1.3 \\
2.7 \\
3.8\end{array}$ & $9.24 *$ \\
\hline
\end{tabular}

Gene frequencies : $\mathrm{A}=0.034, \mathrm{~B}=0.918, \mathrm{C}=0.048$ (fréquences géniques).

* Significant at 0.05 level (significatif au seuil de 5 p. 100). 


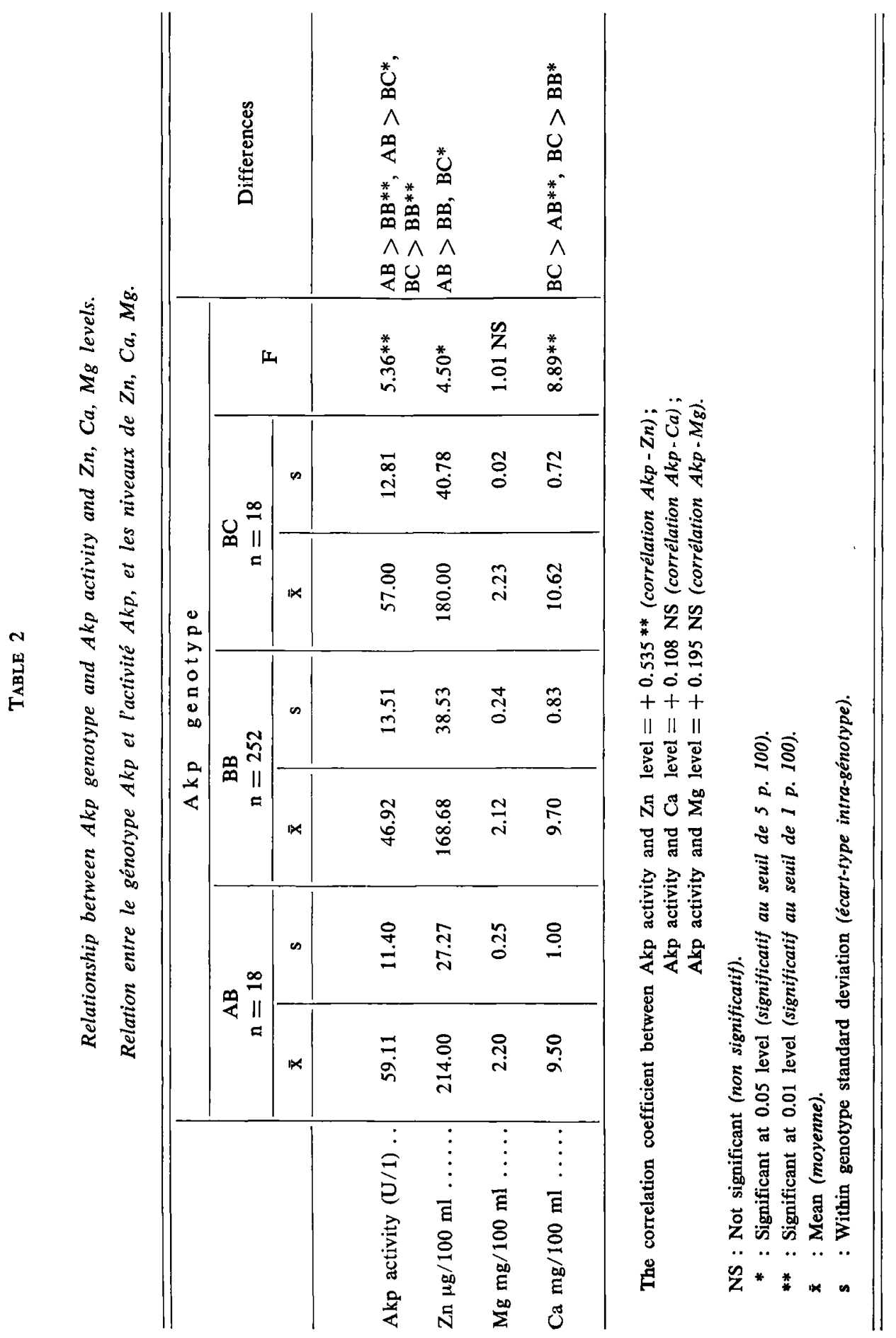


The distribution of the levels of activity for types is shown in table 2. The $A k p$ activity of the $\mathrm{AB}$ type was significantly $(\mathrm{P}<0.01$ and $\mathrm{P}<0.05)$ higher in comparison to the $A k p \mathrm{BB}$ and $\mathrm{BC}$ types. $A k p \mathrm{BC}$ animals had higher $(\mathrm{P}<0.05)$ activity than $A k p$ BB animals.

As seen in table 2, there was a significant association of $A k p$ activity with the $Z n$ level in serum of pigs. The $Z n$ level of $A B$ type was higher than those of $B B$ and $\mathrm{BC}$ types $(\mathrm{P}<0.05)$. The $Z n$ level between $\mathrm{BB}$ and $\mathrm{BC}$ types was not significant $(\mathrm{P}>0.05)$. The correlation coefficient between activity of $A k p$ and $Z n$ level was high $(+0.535)$ and highly significant $(P<0.01)$ (table 2$)$.

The calculated level of the $\mathrm{Ca}$ of Large White pigs varied between 9.50 and $10.62 \mathrm{mg} / 100 \mathrm{ml}$ of serum. There seems to be a relationship between the level of $C a$ and $A k p$ types of pigs. The results pertaining to this relationship are presented in table 2. The $C a$ level of the $\mathrm{BC}$ type was very high. The differences obtained between the $C a$ level of types $\mathrm{BC}$ and types $\mathrm{AB}$ and $\mathrm{BB}$ are highly significant and significant $(\mathrm{P}<0.01$ and $\mathrm{P}<0.05)$. The difference between $\mathrm{AB}$ and $\mathrm{BB}$ types was not significant $(\mathrm{P}>0.05)$. The correlation coefficient between activity of $A \mathrm{kp}$ and $\mathrm{Ca}$ level $(+0.105)$ was not significant (table 2).

Relationship between types of $A k p$ and $M g$ level was not significant $(\mathrm{P}>0.05)$ neither the correlation coefficient between $A k p$ activity and $M g$ level (table 2).

\section{III. - Discussion}

The $\mathrm{A}$ and $\mathrm{C}$ fractions of $A k p$ occur in association with the $\mathrm{B}$ fraction. Therefore in the population studied the $\mathrm{AA}, \mathrm{CC}$ and $\mathrm{AC}$ types did not occur. In the present study the inheritance type of $A k p$ was not analyzed.

The genetic control of pig serum $A k p$ was reported by KIEREK-JASZCZUK $e t$ al. (1979). They stated that it was controlled by three alleles $\left(A k p^{\mathrm{A}}, A k p^{\mathrm{B}}\right.$ and $\left.A k p^{\mathrm{C}}\right)$ in Zlotnicka Pstra breed.

In the study presented here, significant relationships were found between types and activity of $A k p$ as well as $Z n$ and $C a$ levels. On the basis of this work it is concluded that $A k p$ activity as well as level of $Z n$ and $C a$ in serum are genetically controlled through the $A k p$ genotype. However, the variances explained by this locus, for the four quantitative traits considered in table 2, represent rather small fractions (around $10 \mathrm{p} .100$ ) of the within-genotype variances.

It may be legitimate to suggest that the activity of $A k p$ is connected with growth and development (AgERgaARD, 1976) or natural resistance to disease of pigs (PRZYTUlSKI \& PORZECZKOWSKA, 1980).

Similar results for the association between types and $A k p$ activity were obtained by Gahne (1967), Walawski et al. (1977), AgergaARd \& Katholm (1977), Katholm (1978) for cattle serum $A k p$ and by WILCOX (1966), TAMAKI et al. (1975) and TAMAKI et al. (1976) for chicken.

In the population studied the pigs of the BC type had higher level of $C a$ in serum than those of the $\mathrm{BB}$ and $\mathrm{AB}$ types. This indicates a unique function of the $A k p \mathrm{C}$ 
fraction in metabolism of $\mathbf{C a}$ compared to the other fractions. Interactions of $\mathrm{Ca}, \boldsymbol{P}$, $Z n$ and $A k p$ in the chick have been analyzed by Mc Cualg \& Motzok (1974, 1974 a) and they found that the duodenal $A k p$ may regulate the metabolism of $\mathrm{Ca}$ and $\mathrm{Zn}$ via effects on the movements of inorganic phosphate.

\section{Received for publication in January 1982.}

\section{Acknowledgments}

We would like to thank $\mathrm{D}^{\mathrm{r}}$ L. Ollivier (Station de Génétique quantitative et appliquée, I.N.R.A., Centre national de Recherches zootechniques, France) for valuable discussion, and the constructive criticism of this manuscript.

\section{Résumé \\ Relation entre le polymorphisme génétique pour la phosphatase alcaline sérique et l'activité de cette enzyme chez des porcs Large White}

Dans le sérum de 1165 porcs Large White trois types de phosphatase alcaline $(A \mathrm{kp})$ ont été trouvés : AB 6,78 p. $100, \mathrm{BB} 83,60$ p. 100 et BC 9,62 p. 100 . L'activité $A k p$ du type $\mathrm{AB}$ est significativement $(\mathrm{P}<0,01)$ supérieure à celles des types $\mathrm{BB}$ et $\mathrm{BC}$ et le type $\mathrm{BB}$ a une activité inférieure à celle du type $\mathrm{BC}(\mathrm{P}<0,05)$. Le niveau de $\mathrm{Zn}$ du type $\mathrm{AB}$ est supérieur à ceux des types $\mathrm{BB}$ et $\mathrm{BC}(\mathrm{P}<0,05)$. $\mathrm{La}$ corrélation entre l'activité $A k p$ et le niveau de $Z n$ dans le sérum $(+0,535)$ est hautement significative. Le niveau de $\mathrm{Ca}$ du type $\mathrm{BC}$ est supérieur à ceux du type $\mathrm{BB}(\mathrm{P}<0,05)$ et du type $\mathrm{AB}(\mathrm{P}<0,01)$. Sur la base de ces résultats il est conclu que l'activité $A k p$ et les niveaux de $Z n$ et de $C a$ sont génétiquement contrôlés par le génotype pour $A k p$.

\section{References}

AgergaArd N., 1976. Plasma alkaline phosphatase activity and growth in pigs. A rsberetn. Inst. Sterilitetsforsk., 19, 40-50.

Agergaard N., Katholm J., 1977. The activity and the isoenzymes composition of plasma alkaline phosphatase as indicator of weight gain in calves. A rsberetn. Inst. Sterilitetsforsk., 20, 115-129.

BaKer L., 1967. After Saison, 1968.

BASSEY O.A., LOWRY O.H., BROCK M., 1946. After instruction of Alkaline Phosphatase Test. J. biol. Chem., 164, 321.

Comar C.L., Bronner F., 1961. Mineral metabolism. An advanced treatise. Acad. Press, New York and London.

Dinklage H., 1968. The alkaline phosphatase in the pig. XIth Europ. Conf. Anim. Blood Grps Biochem. Polymorph., Warsaw, 329-330.

GAHNE B., 1963. Genetic variation of phosphatase in cattle. Nature, 199, 305-306.

GAHNE B., 1967. Inherited high phosphatase activity in cattle serum. Hereditas, 57, 83-99. 
Katholm J., 1978. Plasma alkaline phosphatase isoenzymes in cattle. A rsberetn. Inst. Sterilitetsforsk., 21, 17-30.

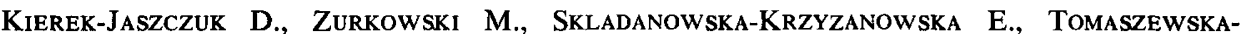
GusZKIEWICZ K., 1978. The genetic polymorphism of blood serum alkaline phosphatase of pigs. XVIth Inter. Conf. Anim. blood Grps Biochem. Polymorph., Leningrad.

Kierek-JaszczuK D., ZurkowsKi M., SkladanowsKa-KrzyzanowsKa E., TomaszewskaGuszKiewicz K., 1979. Serum alkaline phosphatase in pigs. Anim. Blood Grps Biochem. Genet., 10, 15-18.

McCuaig L.W., Motzox I., 1974. Interactions of $\mathrm{Ca}, \mathrm{P}, \mathrm{Zn}$ and alkaline phosphatase in the chick. II - Effect of dietary Ca level. Can. J. Physiol. Pharmacol., 52, 90-95.

McCuaig L.W., Matzok I., 1974 a. Interactions of $\mathrm{Ca}, \mathrm{P}, \mathrm{Zn}$ and alkaline phosphatase, $\mathrm{NaCl}$ and theophylline. Comp. Biochem. Physiol., 48, 663-674.

Przytulski T., PorzeczKowska D., 1980. Genetic markers of resistance to leptospirosis in pigs of Large White Polish breed. Acta Vet., Brno, 49, 237-244.

RASmusen B.A., 1965. Genetics, 51, 767. After Saison, 1968.

SaIson R., 1968. Serum and red enzyme systems in pigs. XIth Europ. Conf. Anim. Blood Grps Biochem. Polymorph., Warsaw, 321-328.

Smithies O., 1955. Zone electrophoresis in starch gel : group variation in the serum of normal human adults. Biochem. J., 61, 629-641.

Stankiewicz A., 1978. Zinc-containing enzymes (in polish). Post. Biochem., 24, 461-479.

Tamaki Y., Watanabe S., Yamada Y., 1975. The genetic role of isozyme types in plasma alkaline phosphatase activity in the young chicken. Anim. Blood Grps Biochem. Genet., 6, $185-193$.

Tamaki Y., Abe T., WaTanabe S., 1976. The contribution of isozymes to alkaline phosphatase activity in chicken plasma. Anim. Blood Grps Biochem. Genet., 7, 225-230.

Walawski K., Kaczmarczyk E., Kolman G., Glogowska B., 1977. Relationship between polymorphism and alkaline phosphatase activity in cattle. Genet. pol., 18, 261-265.

Widdowson R.W., 1967. After Saison, 1968.

WiLcox F.H., 1966. A recessively inherited electrophoretic variant of alkaline phosphatase in chicken serum. Genetics, 53, 799-805.

ZAGULSKA A., 1976. Electrophoteric polymorphism of alkaline phosphatase in pigs of the Zlotnicka Pstra breed. VIth Meet. Pol. Genet. Assoc. (in polish). 